\title{
KINETICS OF TISSUE DISTRIBUTION AND ELIMINATION OF 4,4' -METHYLENE BIS(2-CHLOROANILINE) IN RATS
}

(MBOCA; MOCA; Curene 242; carcinogen; body burden)

MICHAEL C. TOBES, LAWRENCE E. BROWN, BRUCE CHIN* and DAVID D. MARSH

Nuclear Medicine Division, Department of Internal Medicine and *Department of Environment and Industrial Health, The University of Michigan Medical Center, Ann Arbor, MI 48109 (U.S.A.)

(Received November 12th, 1982)

(Accepted December 3rd, 1982)

\section{SUMMARY}

The tissue distribution kinetics and elimination of 4,4'-methylene bis(2-chloroaniline) (MBOCA) in rats was studied after a single dose of $\left[{ }^{14} \mathrm{C}\right] \mathrm{MBOCA}(0.49 \mathrm{mg} / \mathrm{kg}$ body weight, i.v.). The highest concentrations of radioactivity were in the small intestine, liver, adipose, lung, kidney, skin, and adrenals. For most tissues, a rapid decrease in radioactivity was followed by a slower decrease except for the small intestine, adipose and skin which demonstrated transient increases. Subcellular distribution in liver at $1 \mathrm{~h}$ showed radioactivity in all cell fractions. Although very lipophilic, $\left[{ }^{14} \mathrm{C}\right] \mathrm{MBOCA}$ was completely eliminated within $48 \mathrm{~h}$ with the major route via the feces $(73.4 \%)$.

\section{INTRODUCTION}

MBOCA, also known as MOCA and Curene 442, is a curing agent used in polyurethane plastics. The mutagenicity of MBOCA was demonstrated in the Ames' Salmonella/microsome test $[1,2]$. The carcinogenicity of MBOCA was demonstrated in mice [3], rats [3-5], and dogs [6]. After prolonged exposure to MBOCA, the predominant neoplasms were located in lung, liver and bladder [3-6], however, neoplasms were also found in other tissues [3-5].

Very limited information is available on the body burden of MBOCA, its distribution, and its relationship to the sites of observed neoplasms. Since MBOCA is a lipophilic compound with an octanol/water partition coefficient of 1.38 [7], MBOCA might be concentrated in lipid-rich tissues. Alternatively, since carcinogens

Abbreviation: MBOCA, 4,4'-methylene bis(2-chloraniline); MFO, mixed-function oxidase. 
such as MBOCA are metabolized and, therefore, activated by $N$-hydroxylation followed by esterification [7], MBOCA might concentrate into tissues rich in MFO. To assess the body burden of MBOCA and its relationship to the observed neoplasms, we report the kinetics of tissue distribution and elimination of $\left[{ }^{14} \mathrm{C}\right] \mathrm{MBOCA}$ in the rat.

\section{MATERIALS AND METHODS}

\section{Formulation of $I^{14} \mathrm{C} / \mathrm{MBOCA}$}

$\left[{ }^{14} \mathrm{C}\right] \mathrm{MBOCA}$ was obtained from the Amersham Corp. with a spec. act. of 58 $\mathrm{mCi} / \mathrm{mmol}(216 \mu \mathrm{Ci} / \mathrm{mg})$. Radiochemical purity was $>98 \%$ as determined by thinlayer chromatography on silica gel in benzene-acetone (4:1) and cyclohexane-ether (1:1). $\left[{ }^{14} \mathrm{C}\right] \mathrm{MBOCA}$ was formulated in a mixture of $100 \%$ ethanol-Tween-80 redistilled and deionized water (49.6:12.9:37.5).

\section{Animals}

Female Sprague-Dawley rats, obtained from Charles River Breeding Laboratories, Portage, MI, were used in all studies. During all studies, the rats were maintained on feed (Purina Rat Chow) and water ad lib and on a 12:12 light-dark schedule until killing. Rats were individually placed into metabolic cages for the elimination studies.

\section{Tissue distribution studies}

Rats, $235 \pm 34 \mathrm{~g}$ body weight, were lightly anesthetized with ether and dosed i.v. with $0.49 \mathrm{mg} / \mathrm{kg}(106.4 \mu \mathrm{Ci} / \mathrm{kg})$ of $\left[{ }^{14} \mathrm{C}\right] \mathrm{MBOCA}$. After $0.17(10 \mathrm{~min}), 1.0,4.0$, and $16.0 \mathrm{~h}$, the rats were, again, lightly anesthetized and killed by decapitation. 5 or 6 rats were evaluated at each time point. Duplicate samples of up to 20 different tissues from each rat were weighed, oxidized in a Packard Model 306 sample oxidizer, and counted in a Packard Model 3330 liquid scintillation counter with corrections made for background and counter efficiency. Blood samples were obtained by cardiac puncture just prior to decapitation. Skin samples were obtained from the same site distant from the injection site. Brain white matter samples were obtained from the optic nerve and corpus collosum, and brain grey matter samples were obtained from the anterior cerebral cortex. To normalize the differences in animal weights, tissue concentrations are expressed as $\% \mathrm{~kg}$ dose $/ \mathrm{g}$ [8]. The results are reported as mean \pm S.E.M.

\section{Subcellular distribution studies}

4 rats, $312 \pm 29 \mathrm{~g}$ body weight, werc lightly anesthetized with ether and dosed i.v. with $0.37 \mathrm{mg} / \mathrm{kg}(80.1 \mu \mathrm{Ci} / \mathrm{kg})$ of $\left[{ }^{14} \mathrm{C}\right] \mathrm{MBOCA}$. They were anesthetized and killed by decapitation at $1.0 \mathrm{~h}$. Samples, $1.0 \mathrm{~g}$, of each liver were removed, weighed, homogenized in $0.25 \mathrm{M}$ sucrose, and fractionated [9]. Each fraction was analyzed 
for radioactivity by oxidizing and counting as previously described. The distribution is expressed in \%, based on the relative radioactivity recovered in each of the four fractions. The overall recovery of the total radioactivity in the four fractions was $97.74 \pm 5.62 \%$ of the total radioactivity in the intact liver. The results are reported as mean \pm S.D.

\section{Urinary and fecal elimination studies}

4 rats, $229 \pm 13 \mathrm{~g}$ body weight, received mild anesthesia with ether and were dosed i.v. with $0.51 \mathrm{mg} / \mathrm{kg}(109.2 \mu \mathrm{Ci} / \mathrm{kg})$ of $\left[{ }^{14} \mathrm{C}\right] \mathrm{MBOCA}$. Urine and feces were collected at 12, 24, and $48 \mathrm{~h}$. The samples were weighed, oxidized and counted as previously described. The elimination is expressed in cumulative $\%$, mean \pm S.D., of the administered dose.

\section{RESULTS AND DISCUSSION}

As a preliminary assessment of the body burden of MBOCA and its relationship to the sites of the observed neoplasms, we studied the tissue distribution kinetics of $\left[{ }^{14} \mathrm{C}\right] \mathrm{MBOCA}$ after a single dose $(0.49 \mathrm{mg} / \mathrm{kg}$ body weight, i.v. $)$ as shown in Table I. $\left[{ }^{14} \mathrm{C}\right] \mathrm{MBOCA}$ was found in highest concentrations in the small intestine, liver, adipose, lung, kidney, skin, and adrenals, however $\left[{ }^{14} \mathrm{C}\right] \mathrm{MBOCA}$ was distributed throughout the body. $\left[{ }^{14} \mathrm{C}\right] \mathrm{MBOCA}$ was also detected in the brain with approx. a 1.7-fold greater concentration in white matter as compared to grey matter. $\left[{ }^{14} \mathrm{C}\right] \mathrm{MBOCA}$ was rapidly distributed throughout the body, as demonstrated by the organ distribution at $0.17 \mathrm{~h}(10 \mathrm{~min})$. A rapid removal of the radioactivity followed by a slower rate of removal was observed for most tissues. The blood clearance of the injected radioactivity demonstrated similar kinetics. However, small intestine, adipose, and skin demonstrated a short period of increasing radioactivity in contrast to the quick decline in radioactivity observed in all other tissues.

Since the liver contained the greatest concentration of $\left[{ }^{14} \mathrm{C}\right] \mathrm{MBOCA}$ at $0.17 \mathrm{~h}(10$ min), approx. $19 \%$ of the administered dose, and retained much of the radioactivity over time, we studied the subcellular distribution of the radioactivity at $1 \mathrm{~h}$ as a preliminary assessment of the role of metabolism on the deposition of $\left[{ }^{14} \mathrm{C}\right]$ MBOCA. As shown in Table II, radioactivity was found in all cell fractions.

MBOCA has been suggested to be metabolized by cytochrome P-450-dependent hydroxylation and various esterases. Cytochrome P-450 has been detected in various organs with high levels in the adrenal cortex, liver, kidney, lung and ovaries [10-12]. $\left[{ }^{14} \mathrm{C}\right] \mathrm{MBOCA}$ was found to concentrate into these tissues rich in MFO. The sustained retention of the radioactivity in the liver might be due to the formation of a covalent complex with cytochrome P-450 of specific MFO, as has been demonstrated for 1,1,1-trichloro-2,2-bis (p-chlorophenol) ethane [13].

The concentration of $\left[{ }^{14} \mathrm{C}\right] \mathrm{MBOCA}$ into the small intestine, adipose, and skin suggests that other dynamics are involved. The transient increase of radioactivity in 
TABLE I

TIME-DEPENDENT TISSUE DISTRIBUTION OF $\left[{ }^{14} \mathrm{C}\right] \mathrm{MBOCA}$ IN RATS

\begin{tabular}{|c|c|c|c|c|}
\hline \multirow[t]{2}{*}{ Tissue } & \multicolumn{4}{|c|}{ Tissue Concentration, $\% \mathrm{~kg}$ dose $/ \mathrm{g}$ (Mean \pm S.E.M.) } \\
\hline & $\begin{array}{l}0.17 \mathrm{~h} \\
(\mathrm{n}=5) \\
\end{array}$ & $\begin{array}{l}1.0 \mathrm{~h} \\
(\mathrm{n}=5)\end{array}$ & $\begin{array}{l}4.0 \mathrm{~h} \\
(\mathrm{n}=5)\end{array}$ & $\begin{array}{l}16.0 \mathrm{~h} \\
(\mathrm{n}=6)\end{array}$ \\
\hline Adipose & $0.0644+0.0045$ & $0.1826 \pm 0.0364$ & $0.1449 \pm 0.0061$ & $0.0411 \pm 0.0047$ \\
\hline Adrenals & $0.3846 \pm 0.0121$ & $0.1136 \pm 0.0141$ & $0.0067 \pm 0.0027$ & $0.0406 \pm 0.0028$ \\
\hline Bladder & $0.0656 \pm 0.0094$ & $0.0198 \pm 0.0040$ & $0.0271 \pm 0.0059$ & $0.0052 \pm 0.0004$ \\
\hline \multicolumn{5}{|l|}{ Brain } \\
\hline Grey & - & $0.0281 \pm 0.0023$ & - & - \\
\hline White & - & $0.0485 \pm 0.0216$ & - & - \\
\hline Heart & - & $0.0427 \pm 0.0022$ & - & - \\
\hline \multicolumn{5}{|l|}{ Intestine } \\
\hline Large & $0.0698 \pm 0.0041$ & $0.0594 \pm 0.0270$ & $0.0115 \pm 0.0004$ & $0.0103 \pm 0.0007$ \\
\hline Small & $0.2254 \pm 0.0746$ & $0.2635 \pm 0.0755$ & $0.2996 \pm 0.1027$ & $0.0163 \pm 0.0020$ \\
\hline Kidney & $0.1847 \pm 0.0053$ & $0.1346 \pm 0.0091$ & $0.0918 \pm 0.0045$ & $0.0607 \pm 0.0044$ \\
\hline Liver & $0.4964 \pm 0.0099$ & $0.2458 \pm 0.0080$ & $0.1694 \pm 0.0104$ & $0.1068 \pm 0.0102$ \\
\hline Lung & $0.2490 \pm 0.0149$ & $0.1702 \pm 0.0106$ & $0.1257 \pm 0.0115$ & $0.0737 \pm 0.0060$ \\
\hline Muscle & - & $0.0318 \pm 0.0036$ & & \\
\hline Ovaries & $0.1940 \pm 0.0120$ & $0.0489 \pm 0.0061$ & $0.0395 \pm 0.0005$ & $0.0264 \pm 0.0032$ \\
\hline Pancreas & $0.2036 \pm 0.0102$ & $0.0514 \pm 0.0035$ & - & - \\
\hline Skin & $0.0800 \pm 0.0127$ & $0.1264 \pm 0.0404$ & $0.0375 \pm 0.0026$ & $0.0058 \pm 0.0006$ \\
\hline Spleen & $0.0871 \pm 0.0103$ & $0.0328 \pm 0.0018$ & - & - \\
\hline Stomach & $0.1576 \pm 0.0099$ & $0.0466 \pm 0.0053$ & $0.0408 \pm 0.0141$ & $0.0160 \pm 0.0052$ \\
\hline Thyroid & - & $0.0380 \pm 0.0050$ & - & - \\
\hline Uterus & - & $0.0307 \pm 0.0022$ & - & - \\
\hline Blood & $0.0903 \pm 0.0063$ & $0.0333 \pm 0.0013$ & $0.0270 \pm 0.0014$ & $0.0100 \pm 0.0005$ \\
\hline
\end{tabular}

TABLE II

SUBCELLULAR DISTRIBUTION OF $\left[{ }^{14} \mathrm{C}\right] \mathrm{MBOCA}$ IN RAT LIVER AT $1.0 \mathrm{~h}$

\begin{tabular}{ll}
\hline Fraction $(\times g)$ & $\%$ \\
& Distribution $^{\mathrm{a}}$ \\
\hline $0-500$ & $28.72 \pm 2.07$ \\
$500-12,000$ & $19.65 \pm 0.27$ \\
$12000-100000$ & $20.08 \pm 1.14$ \\
$>100000$ & $31.56 \pm 2.29$ \\
\hline
\end{tabular}

${ }^{\text {a }}$ Each value is based on the relative radioactivity recovered in each of the four fractions and expressed as the mean \pm S.D. of the value for that fraction from 4 rats.

skin and adipose, accompanying the rapid removal of radioactivity from other tissues, may result from a shift of the biodistribution to those sites of higher lipid content. The lipophilicity of MBOCA might also explain the greater concentration into brain white matter as compared to grey matter and the detection of radioactivi- 


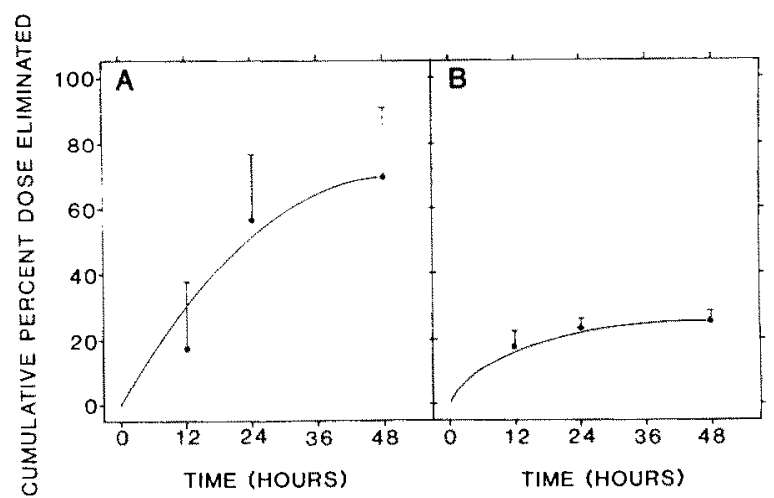

Fig. 1. Cumulative elimination kinetics of $\left[{ }^{14} \mathrm{C}\right] \mathrm{MBOCA}$ from rats via (A) feces and (B) urine. The mean \pm S.D. is plotted for each time point.

ty in all membrane-containing fractions of the liver. The transient increase and high uptake into the small intestine suggest that other dynamics are involved such as the re-absorption of $\left[{ }^{14} \mathrm{C}\right] \mathrm{MBOCA}$ metabolites as they pass through the small intestine.

The elimination kinetics of $\left[{ }^{14} \mathrm{C}\right] \mathrm{MBOCA}$ was also studied to assess the body burden of MBOCA. As shown in Fig. $1\left[{ }^{14} \mathrm{C}\right] \mathrm{MBOCA}$ was rapidly eliminated from the body with the total cumulative urinary and fecal elimination of 35.4, 79.4, and $94.6 \%$ at 12,24 , and $48 \mathrm{~h}$, respectively. The major route of elimination was via the feces, which represented $73.4 \%$ of the total cumulative $\%$ dose at $48 \mathrm{~h}$.

These kinetic studies in the rat indicate whole body uptake occurs within minutes and elimination occurs within $48 \mathrm{~h}$ after a single i.v. dose. The major route of detoxification and elimination appears to be metabolism by the liver, movement through the intestinal tract, and removal via the feces. The observed kinetics of tissue uptake, distribution, and elimination may, however, be dependent on the route of exposure as well as the species studied. There are known species differences in MFO distribution [14]. Skin absorption is a major route of human exposure [15]. Preliminary reports suggest, however, that the elimination kinetics of $\left[{ }^{14} \mathrm{C}\right] \mathrm{MBOCA}$ was not affected by dose or route of administration in rat, dog, or man $[16,17]$. A preliminary report on the distribution of the radioactivity at $48 \mathrm{~h}$ after a single i.p. or p.o. dose of [ $\left.{ }^{14} \mathrm{C}\right] \mathrm{MBOCA}$ into 2 rats for each route demonstrated concentration of the radioactivity into the liver and adipose tissue [16]. These observations suggest that the route of administration does not affect the tissue distribution.

Although we have observed concentration of $\left[{ }^{14} \mathrm{C}\right] \mathrm{MBOCA}$ into those tissues where metabolism of MBOCA might occur and where subsequent neoplasms have been observed, we do not know the activated metabolite involved and the tissue dose required to achieve carcinogenesis [18]. Multiple exposures to MBOCA might demonstrate greater and more persistent concentrations of MBOCA in the liver, the 
major site of neoplasms. Our studies indicate that a single exposure at a subpharmacologic dose in the rat is rapidly distributed and eliminated. Further studies will be needed to fully understand the body burden of MBOCA and its relationship to carcinogenesis.

\section{ACKNOWLEDGEMENTS}

This work was supported in part by a grant from the State of Michigan Toxic Substances Control Commission. The authors want to thank Ms. Linder Markham for help in preparing the manuscript.

\section{REFERENCES}

1 J. McCann, E. Choi, E. Yamasaki and B.N. Ames, Detection of carcinogens as mutagens in the Salmonella/microsome test: assay of 300 chemicals, Proc. Natl. Acad. Sci. USA, 72 (1975) 5135-5139.

2 D. Anderson and J.A. Stiles, An evaluation of 6 short term tests for detecting organic chemical carcinogenesis. Appendix 2. The bacterial mutation test, Br. J. Cancer, 37 (1978) 924-930.

3 A.B. Russfield, F. Homburger, E. Bogen, C.D. van Dongen, E.K. Weisburger and J.H. Weisburger, 'The carcinogenic effect of 4,4'-methylene bis(2-chloroaniline) in mice and rats, Toxicol. Appl. Pharmacol., 31 (1975) 47-54.

4 E.F. Stula, J.A. Zapp Jr. and J.W. Clayton Jr., Experimental neoplasia in rats from oral administration of $3,3^{\prime}$-dichlorobenzidine, $4,4^{\prime}$-methylene-bis(2-chloroaniline), and 4,4'-methylenebis(2-methylaniline), Toxicol. Appl. Pharmacol., 31 (1975) 159-176.

5 C. Kommineni, D.H. Groth, I.J. Frockt, R.W. Voelker and R.P. Stanovick, Determination of the tumorigenic potential of methylene-bis-ortho-chloroaniline, J. Environ. Pathol. Toxicol., 2 (1979) 149-171.

6 E.F. Stula, J. Barnes, H. Sherman, C.F. Reinhardt and J.A. Zapp Jr., Urinary bladder tumors in dogs from 4,4'-methylene-bis-(2-chloroaniline) (MOCA), J. Environ. Pathol. Toxicol., 1 (1978) $31-50$.

7 I.B. Glowinski, H.E. Radtke and W.W. Weber, Genetic variation in N-acetylation of carcinogenic arylamines by human and rabbit liver, Mol. Pharmacol., 14 (1978) 940-949.

8 A.S. Kirschner, R.D. Ice and W.H. Beierwaltes, Reply, J. Nucl. Med., 16 (1975) 248-249.

$9 \mathrm{~J}$. Nedergaard and B. Cannon, Overview-preparation and properties of mitochondria from different sources, Methods Enzymol., 55 (1979) 3-28.

10 R.H. Wickramasinghe, Biological aspects of cytochrome P-450 and associated hydroxylation reactions, Enzyme, 19 (1976) 348-376.

11 M.J. Coon and K.P. Vastis, Biochemical studies on chemical carcinogenesis: Role of multiple forms of liver microsomal cytochrome P-450 in the metabolism of benzo[a]pyrene and other foreign compounds, Polycyclic Hydrocarbons and Cancer, 1 (1978) 335-360.

12 J.C. Connelly and J.W. Bridges, The distribution and role of cytochrome P 450 in extrahepatic organs, Prog. Drug Metab., 5 (1980) 1-111.

13 T.J. Wisnieff, A. Gold and S.A. Evans Jr., N21, N22 Cis-bridged tetraarylporphyrins from oxidation of tetraarylporphinatoiron(II)-carbene complexes, J. Am. Chem. Soc., 103 (1981) 5616-5618.

14 R. Kato, Characteristics and differences in the hepatic mixed function oxidases of different species, Pharmacol. Ther., 6 (1979) 41-48. 
15 A.L. Linch, G.B. O'Connor, J.R. Barnes, A.S. Killian Jr. and W.E. Neeld, Methylenebis-orthochloroaniline [MOCA (Registered trademark]: Evaluation of hazards and exposure control, Am. Indust. Hyg. Assoc. J., 32 (1971) 802-819.

16 P.B. Farmer, J. Rickard and S. Robertson, The metabolism and distribution of $4,4^{\prime}$-methylene bis (2-chloroaniline) (MBOCA) in rats, J. Appl. Toxicol., 1 (1982) 317-322.

17 The State of Michigan Toxic Substance Control Commission: Recent Research on biological properties and environmental fate of MBOCA. March 10, 1982. Lansing, MI.

18 P.G. Watanabe, J.C. Ramsey and P.J. Gehring, Pharmacokinetics and metabolism of industrial chemicals, Prog. Drug Metab., 5 (1980) 311-343. 